\title{
Key Lessons to Sustain Continuous Improvement: A Case Study of Four Companies
}

\author{
Luis Paipa-Galeano(iD), César A. Bernal-Torres (D), Luis M. Agudelo-Otalora (D), \\ Yavar Jarrah-Nezhad iD, Heither A. González-Blanco iD \\ Universidad de La Sabana (Colombia) \\ luis.paipa@unisabana.edu.co,cesar.bernal@unisabana.edu.co,mauricio.agudelo@unisabana.edu.co, \\ yavar.jarrah@unisabana.edu.co,heithergobl@unisabana.edu.co
}

Received: July 2019

Accepted: February 2020

\section{Abstract:}

Purpose: This paper analyses the success factors and barriers of sustainable continuous improvement practices in terms of company's maturity level. The key factors are necessary to establish strategies that reduce the risk of improvement failure and increase the company's maturity level.

Design/methodology/approach: The paper presents a multi-case analysis of the success factors in the implementation of continuous improvement. This lead to comparison between the factors identified from the literature review and the practice of the continuous improvement programs in four large successful companies located in Bogota, Colombia applying Bessant's maturity model.

Findings: The results identified five success factors and three barriers that companies should consider while implementing sustainable continuous improvement programs. The key success factors are availability of resources; management commitment; employee participation in improvement task identification; clear and realistic objectives; and, finally, existence of a leader. The major barriers are lack of alignment between organizational and continuous improvement objectives; lack of motivation in the team; and, resistance to change. The results confirm that, in spite the high maturity, it is necessary to align the organizational and continuous improvement objectives.

Research limitations/implications: Since this research is a multi-case study, it is limited in terms of results generalizability for companies of different sizes, sectors and context. The academic and practical contribution of this paper is providing a better understanding of sustainable continuous improvement practices in Latin-American emerging economies.

Originality/value: The present research provides an integral analysis of the key success factors, the barriers, the level of maturity and the behaviours that the companies should implement to achieve the sustainability of continuous improvement in emerging economies such as Colombia.

Keywords: success factors, barriers, improvement maturity model, continuous improvement sustainability, kaizen, multi-case study, emerging economies

\section{To cite this article:}

Paipa-Galeano, L., Bernal-Torres, C.A., Agudelo-Otalora, L.M., Jarrah-Nezhad, Y., \& González-Blanco, H.A. (2020). Key Lessons to Sustain Continuous Improvement: A Case Study of Four Companies. Journal of Industrial Engineering and Management, 13(1), 195-211. https:/ /doi.org/10.3926/jiem.2973 


\section{Introduction}

Porter (1985) affirm that strategic innovations in the company's globalization process generate competitive advantages since they include product redefinition, cost reduction, adaptation to customer needs, and changes in the design and distribution of production, among others. Radical or incremental changes ensure achievement of these innovations. As a result, some companies opt for radical changes, such as processes redesign or reengineering (Borgianni, Cascini \& Rotini, 2015; Hammer \& Champy, 1994). At the implementation time, radical changes are challenging and need large investments. However, other companies prefer incremental changes known as continuous improvement (CI) due to the advantages of easy implementation and low costs (Imai, 2012; Singh \& Singh, 2015).

In this paper, we analyse the success factors and barriers that lead to CI sustainability (CIS), for this reason, we understand CIS as an organization's ability to maintain performance improvements in all organizational system and processes, involving all organizational participants through a planned, organized and systematic process.

Different authors agree that sustainability is maintaining the implemented improvement behaviours and note that the company should increase and sustain cumulative improvement (Bateman \& David, 2002; Bessant, Caffyn \& Gallagher, 2001; Caffyn, 1999; Dale, Boaden, Wilcox \& McQuater, 1997; García-Sabater \& Marín-García, 2009; Jaca, Suárez-Barraza, Viles, Mateo \& Santos, 2011; Juran, Ballester \& Medina, 1990; Michcol, Cano, Farías \& Morales, 2012).

However, studies related to CI processes have shown that implemented improvements often cannot be sustained (Anand, Ward, Tatikonda \& Schilling, 2009; Bateman \& David 2002; Dale et al., 1997; Formento, Chiodi, Cusolito, Altube \& Gatti, 2013; McLean, Antony \& Dahlgaard, 2017). This is mainly due to the lack of organizational culture; collective learning; leadership and operators' commitment; clear objectives and indicators; availability of resources, project identification and selection; data availability; stakeholder representation; and, structured methodology (Jaca et al., 2011; Albors, Hervás-Oliver \& Segarra-Oña, 2009; García-Sabater \& Marín-García, 2009; González-Aleu \& Van Aken, 2016).

The main objective of the present research is to identify the key lessons to sustain CI by performing a multi-case study in four successful companies in Colombia. This goal arises from the gaps identified in the literature such as lack of multi-case studies in continuous improvement sustainability, lack of empirical analysis of the CIS conceptual models in Latin America and at last, lack of evidence about the generality and validity of the CIS models identified in developed countries in the companies of emerging economies.

\section{Literature Review}

\subsection{Continuous Improvement Sustainability}

There is no consensus among researchers regarding the definition of the CIS. According to Upton (1996), the CIS definition is maintaining implemented improvements while obtaining new opportunities to continue improving gradually. In addition, CIS is all standard development based on the improvements and an expansion of the gained knowledge to other areas (Bateman, 2005; Bateman \& David, 2002; Bessant, Caffyn \& Gallagher, 2001). Zairi (2005) defines CIS as an organization's ability to adapt to the changes in business environment in order to obtain and apply the best practices, methodologies and techniques that ensure the superior organizational performance. In summary, these definitions share the idea that CIS is an organization's ability to maintain performance improvements.

There have been many attempts by researchers to develop a unique model that guaranties the CIS and the company's success. However, there is no consensus among researchers regarding the success and failure factors from the conceptual point of view. Additionally, the results of applying different models in organizations are rather controversial, and there is no general agreement on the main success factors.

Bessant and Caffyn (1997) made one the first widely accepted effort and developed a maturity model based on series of evolutionary levels of CI functions in relation to the corresponding facilitating elements. This model evaluates the conditions that ensure the development of CI capabilities. 
In Spain, Garrigós, Oliver and Oña (2009) applied a survey of 55 questions to address the CI practices. They indicated that the implementation of CI required a clear methodology and the knowledge to apply CI tools. They concluded that it is important to maintain the management commitment related to time and resources, while assigning specific working groups dedicated to the CI. García-Sabater and Marín-García (2009) identified new success factors such as the promoter of $\mathrm{CI}$, accordance of the structure with the CI processes, clear functions definition, and standardizing the methodology before applying $\mathrm{CI}$ in other parts of the organization.

Further, Michcol et al. (2012) explored the concept of maturity by surveying the company's staff in order to evaluate their perception of organizational enablers and their influence to develop a successful CI Strategy. They conducted an interview of the CI leaders based on the Bessant model and identified the factors that lead to their success. These factors are the following: the deployment of correct CI strategic plan throughout the organization, definition and systematic measurement of objectives, leadership commitment, the organizational structure that supports CI, application of a formal methodology, and employee motivation.

González-Aleu and Van Aken (2016) conducted a systematic literature review from 98 articles between 1995 and 2014 that resulted in identification of 53 potential success factors classified into four groups related to task design, team design, organization, and CI processes. It is noticeable in the achieved results that first, the list of articles included 57 academic journal articles out of which 43 applied single case study method that indicates the lack of methodological diversity in the past literature. Secondly, the classification of the literature implicates the lack of single or group dominant publications outlets this means that the research area is not mature and new research can add to the prior knowledge. Thirdly, the researchers identified 300 unique authors from 22 different countries; however, more than $85 \%$ of this research occurred in developed countries including U.S., U.K., Canada, Sweden, Australia, Spain, Taiwan and Singapore. The rest of the published articles are in the emerging economies such as India, and Mexico. It is evident that just a small number of the conducted research are in the emerging countries and even less quantity in Latin America. It is remarkable that despite the fact that this research area appears to be relatively young, in the recent years, a dramatic increase in academic research interest in analysing critical success factors for continuous improvement processes (CIP) is evident. For instance, there were less than three articles published per year until 2007, however, more than 60 new authors have dedicated their research to CI success factors and the publishing rate has been significantly higher in the recent years. This demonstrates the importance of further research in this area for both the academy and the industry.

In contrast, McLean and Antony (2014) focused on the themes that lead to CI failure. The themes they identified are motives and expectations, organizational culture and environment, the management leadership, implementation approach, training, project management, employee involvement levels, and feedback and results.

For identifying other barriers to the success of CIS, Sánchez-Ruiz, Blanco and Diaz (2018) conducted an in-depth literature review and categorized the failure factors to 13 items. These factors are the lack of time, knowledge or experience about CI, clarity of CI objectives, suitable measurement system, management commitment, employee motivation, monitoring of proposed improvements, resources, change acceptance (employees, unions), profitability of the project, integration between CI aims and company competitive strategy, learning from mistakes, and formal process to solve problems.

The researchers conducted a great number of literature reviews and empirical studies to identify critical success factors (CSFs) and barriers related to the successful implementation of CI programs. The collected data are from companies of different sizes, economic sectors and countries that implemented continuous improvement initiatives program (Antony \& Banuelas, 2002; Bateman \& David 2002; Jaca et al., 2011; Jayaraman, Kee \& Soh, 2012; Michcol et al., 2012).

Based on the prior revision, and considering that there are many key success factors identified to sustain CI, the present study identifies the following factors with higher occurrences in the literature:

1. Education and training: Providing some level of training to the workforce is necessary for implementing any CI initiative (McLean \& Antony, 2014). Training program should include skills such as problem identification and solving, and also data analysis and teamwork (Berger, 1997; Bessant \& Francis, 1999; Jørgensen, Boer \& Laugen, 2006; Sánchez-Ruiz, Blanco \& Gomez-Lopez, 2019). As a result, the training increases employee confidence and facilitates adaption to change (López, Morales, Toledo \& Delgado, 2009). 
2. Commitment and support: The main responsibility of the management is to promote and support the culture of improvement among employees (Berger, 1997; He, 2009) and to be a facilitator of the improvement process (García-Sabater \& Marín-García, 2009; Bateman \& Rich, 2003).

3. Availability of resources: The lack of resources is a clear cause of failure in the implementation of improvement programs (Bateman \& Rich, 2003). Resources not only include financial but also time, staff, access to equipment and infrastructure, and training (Prajogo \& Sohal, 2004).

4. Leadership: The leader is responsible for guiding the work team to apply different CI tools, coordinate activities, manage the resources and offer the improvement training. He should be a genuine improvement advocate (García-Sabater \& Marín-García, 2009; Bateman \& Rich, 2003; Sánchez-Ruiz et al., 2019; McLean \& Antony, 2014).

5. Indicators and measurement of improvement: CI measurement and interventions affect the process in progress (Bessant \& Francis, 1999; He, 2009) and allow learning from the outcomes (Bateman \& Rich, 2003; Sánchez-Ruiz et al., 2019; McLean \& Antony, 2014).

6. Official improvement teams: Interdisciplinary work teams formalize the planning and deployment processes, and they participate at all levels (Prado, Fernández-González \& García-Lorenzo, 2004). These teams should develop an adequate organization plan based on the scope of the implementation, considering clear roles and defined hierarchies for efficient monitoring and control (García-Sabater \& Marín-García, 2009).

7. Formal methodology: It facilitates CI progress in an orderly and formalized manner (Caffyn, 1999; McLean \& Antony, 2014). According to Upton (1996), the methodology provides focus, motivation and empowerment.

8. Clear and achievable objectives: They are demanding, specific, and adjusted to the reality of the organization's resources and external forces. These objectives specify and delimit the scope of the planned goals (Prajogo \& Sohal, 2004; Sánchez-Ruiz et al., 2019).

9. Policies, standards and procedures: They are criteria, parameters and guides that assure the success of CI programs. According to Cooney and Sohal (2004), teams that generate clear policies and standards achieve success. In addition, Barraza and Dávila (2009) state that a fundamental CI principle is to standardize operations in order to sustain the obtained achievements.

10. Employee involvement: It begins with the employees' desire to solve problems in the matters that affect them directly (Jaca, Viles, Mateo \& Santos, 2012). These include problems in conception, planning and execution of the CI processes. Thus, the teams achieve more commitment, empowerment and appropriation (Prajogo \& Sohal, 2004; Bateman, 2005).

11. Recognition systems: They are important factors at the time of generating commitment and motivation in the team. The recognition for the achievements can be whether material or immaterial (Bateman \& Rich, 2003; Caffyn, 1999; García-Sabater \& Marín-García, 2009).

12. Standardized assessment system: This system accompanied with learning from the outcomes is essential for the effective implementation of any CI process (Bateman \& Rich, 2003).

The principal barriers frequently mentioned in the literature are:

1. Resistance to change: When implementing a CI plan, involved persons tend to think that the improvement happens with an increase in the workload. Additionally, natural human behaviour is to put up barriers and resist the possibility of change (Bessant \& Francis, 1999).

2. Lack of motivation in the team: The team should see and understand each proposed activity as part of daily work and not as extraordinary resources or as activities outside the working hours; the team appropriates these activities in such a way that their execution is a win-win situation (Bateman \& Rich, 2003).

3. Difficulties in communication: Some members do not comprehend the company's global objectives and the responsibilities of others; this is due to the lack of communication between all employees involved (Bateman \& Rich, 2003). 
4. Lack of alignment between the organization's objectives: It is necessary for the CI program's success to follow the same goal as strategic objectives of the company. It is necessary for the CI program to obtain high priority in order to succeed (Caffyn, 1999; Dale et al., 1997; Upton, 1996).

\subsection{Assessment of the Sustainability of Continuous Improvement}

In the literature, there are a variety of assessment models to measure the evolution and sustainability of CI behaviours in an organization (Upton, 1996; Bateman \& Rich, 2003; and Bessant et al., 2001). This paper applies the Bessant et al. (2001) model, which is widely accepted and frequently referenced by other studies (Bhuiyan, Baghel \& Wilson, 2006; Jørgensen et al., 2006). Bessant et al. (2001) developed this model in the Continuous Improvement Research for Competitive Advantage framework (CIRCA). The model allows classifying and evaluating organizations based on improvement practices and specific individual behaviours that support CI sustainability. The model defines five levels of evolution that converts into skills that people develop for the understanding and construction of CI (Bessant et al., 2001). The intention of this skill classification is to help companies understand their relative position in comparison to other companies in terms of plan development and capabilities expansion.

At the first level (precursor), the organization can randomly generate improvements or try to solve problems through processes, but there are no formal or structured efforts to improve the organization. At the second level (structured $\mathrm{CI}$ ), the company starts an improvement initiative, and a high proportion of the staff participates, thus creating a formal commitment to building a CI system. At the third level (strategic CI), the organization commits to linking CI behaviours to its broader strategic concerns. At the fourth level (proactive $\mathrm{CI}$ ), the organization attempts to delegate autonomy and strengthen individuals and groups to manage their own processes. Finally, at the fifth level (full capacity for $\mathrm{CI}$ ) the organization demonstrates a persistent capacity to learn and convert it into the capacity to innovate.

According to this model, to start CI, a company must engage in a series of routines or habits (Bessant \& Francis, 1999; Bessant et al., 2001). These routines are composed of a set of behaviours, which comprise actions or responses of the company's personnel under certain circumstances. The model proposes eight (8) routines, which comprise 36 behaviours (Bessant et al., 2001) (the basis of the questions applied in this research - Table 1).

\begin{tabular}{|c|c|c|}
\hline Level & Routine & Behaviours \\
\hline $\begin{array}{l}\text { Level } 1 \\
\text { Precursor }\end{array}$ & $\begin{array}{l}\text { (1) Basic } \\
\text { continuous } \\
\text { improvement }\end{array}$ & $\begin{array}{l}\text { 1. A belief shared by all the company's personnel that improvements in small steps are } \\
\text { valuable and that everyone can participate in the identification of problems and } \\
\text { the generation of incremental improvements. } \\
\text { 2. When something goes wrong, the natural reaction of the staff at all levels of the } \\
\text { company is to look for the root cause of the problem instead of looking for the } \\
\text { culprit. } \\
\text { 3. The collaborators use a formal system for the problem identification and problem- } \\
\text { solving cycle. }\end{array}$ \\
\hline \multirow{2}{*}{$\begin{array}{l}\text { Level } 2 \\
\text { Structured } \\
\text { continuous } \\
\text { improvement }\end{array}$} & $\begin{array}{l}\text { (2) Involvement } \\
\text { of operators } \\
\text { in continuous } \\
\text { improvement }\end{array}$ & $\begin{array}{l}\text { 4. The collaborators use appropriate tools and techniques to support continuous } \\
\text { improvement. } \\
\text { 5. The collaborators measure indicators to control the improvement process. } \\
\text { 6. The collaborators (individually or as groups) carry out continuous improvement } \\
\text { activities - they participate in the continuous improvement process. } \\
\text { 7. The team makes the decision about the implementation of the proposals for } \\
\text { improvement in a clearly defined manner. }\end{array}$ \\
\hline & $\begin{array}{l}\text { (3) Support for } \\
\text { continuous } \\
\text { improvement }\end{array}$ & $\begin{array}{l}\text { 8. The managers support the continuous improvement process by allocating time, } \\
\text { money, space or other resources necessary for continuous improvement. } \\
\text { 9. The managers recognize the contributions of collaborators to continuous } \\
\text { improvement and reward them formally (not necessarily with economic } \\
\text { incentives). } \\
\text { 10. The managers lead by example, actively participating in the design and } \\
\text { implementation of continuous improvement. } \\
\text { 11. The managers support experimentation and do not punish mistakes but instead } \\
\text { encourage learning from them. }\end{array}$ \\
\hline
\end{tabular}




\begin{tabular}{|c|c|c|}
\hline Level & Routine & Behaviours \\
\hline \multirow{2}{*}{$\begin{array}{l}\text { Level } 3 \\
\text { Improvement } \\
\text { oriented to } \\
\text { objectives }\end{array}$} & $\begin{array}{l}\text { (4) Focused } \\
\text { improvement }\end{array}$ & $\begin{array}{l}\text { 12. Individuals and groups use strategic company objectives to focus and prioritize } \\
\text { improvements. } \\
\text { 13. All employees understand (for example, they can explain to others) the strategic } \\
\text { objectives of the company or department. } \\
\text { 14. Individuals and groups evaluate the proposed changes against the objectives of the } \\
\text { company or department before starting the problem-solving cycle or } \\
\text { implementing a solution to ensure that these are consistent. } \\
\text { 15. Individuals and groups measure and evaluate the outcomes of their improvement } \\
\text { activities and the impact of these on strategic or departmental objectives. } \\
\text { 16. Continuous improvement activities integrate into the usual work of individuals or } \\
\text { groups and are not distinct parallel activities. }\end{array}$ \\
\hline & $\begin{array}{l}\text { (5) Integrate } \\
\text { continuous } \\
\text { and structured } \\
\text { improvement }\end{array}$ & $\begin{array}{l}\text { 17. The structure and infrastructure of the company and the continuous improvement } \\
\text { system support and reinforce each other through continuous assessment. } \\
\text { 18. The person or group responsible for the design of the continuous improvement } \\
\text { system ensures that the system fits with the current structure and infrastructure of } \\
\text { the company. } \\
\text { 19. The employees responsible for a certain system or process of the company } \\
\text { perform periodic reviews to assess whether these processes remain compatible } \\
\text { with the continuous improvement system. } \\
\text { 20. The employees responsible for the continuous improvement system ensure that } \\
\text { when a plan consists of a major organizational change, the possible impacts on } \\
\text { the continuous improvement system are predetermined and they consider the } \\
\text { necessary adjustments. }\end{array}$ \\
\hline \multirow{2}{*}{$\begin{array}{l}\text { Level } 4 \\
\text { Proactive } \\
\text { continuous } \\
\text { improvement }\end{array}$} & $\begin{array}{l}\text { (6) Improvement } \\
\text { expanded }\end{array}$ & $\begin{array}{l}\text { 21. The collaborators, in addition to their operational roles, cooperate with people } \\
\text { from other areas to perform continuous improvement (for example, by } \\
\text { participating in multidisciplinary teams). } \\
\text { 22. The collaborators understand and share a comprehensive vision of the company } \\
\text { (they understand the processes and feel ownership). } \\
\text { 23. The collaborators direct their continuous improvement activities towards } \\
\text { customers, both internally and externally. } \\
\text { 24. There are specific projects for continuous improvement with the participation of } \\
\text { stakeholders outside the company (customers, suppliers, etc.). } \\
\text { 25. The representative activities of continuous improvement incorporate personnel } \\
\text { from different organizational levels of the company. }\end{array}$ \\
\hline & $\begin{array}{l}\text { (7) Programme } \\
\text { improvement }\end{array}$ & $\begin{array}{l}\text { 26. A continuous improvement system applies a nonstop processes evaluation and } \\
\text { development. A responsible individual or group assesses the system and measures } \\
\text { the incidence of continuous improvement activities and their outcomes. } \\
\text { 27. There is a planned cyclical process revision and modification. } \\
\text { 28. Managers carry out a periodic review of the continuous improvement system by } \\
\text { analysing its relationship with the organization as a whole in order to make } \\
\text { substantial changes if deemed necessary. } \\
\text { 29. Management supports the development and continuous evolution of the continuous } \\
\text { improvement system by allocating enough resources (time, money, personnel). }\end{array}$ \\
\hline $\begin{array}{l}\text { Level } 5 \\
\text { Full capacity } \\
\text { for continuous } \\
\text { improvement }\end{array}$ & $\begin{array}{l}\text { (8) Learning } \\
\text { organization }\end{array}$ & $\begin{array}{l}\text { 30. The collaborators learn from their experiences, both positive and negative. } \\
\text { 31. Employees in the company look for opportunities to learn or develop (for } \\
\text { example, active experimentation, establishing their own learning objectives). } \\
\text { 32. Employees and groups at all levels share and make available what they have learned } \\
\text { from their experiences at work. } \\
\text { 33. The company articulates and consolidates (by way of sharing) the learning of } \\
\text { individuals and groups. } \\
\text { 34. Managers accept and, when necessary, participate in all the learning that takes place } \\
\text { in the company. } \\
\text { 35. The collaborators and teams ensure that their learning is captured using } \\
\text { mechanisms that the company has established for that purpose. } \\
\text { 36. The designated employees use mechanisms to deploy the previously captured } \\
\text { learning throughout the entire company. }\end{array}$ \\
\hline
\end{tabular}

Table 1. Extension of the Bessant et al. (2001) model by Marín-García and García-Sabater (2010, p.13) 
In order to determine the maturity level of a company's CI system, it is necessary to calculate the average of the scores for each question (Likert scale of 1 to 5) defined in each of the eight factors. Subsequently, an average value of the averages is determined (Bessant \& Francis, 1999; Bessant et al., 2001). The resulting value is then analysed to define maturity levels of $\mathrm{CI}$ with the following scale (Table 2).

\begin{tabular}{|l|l|}
\hline Obtained value & Maturity level of continuous improvement \\
\hline Between $0 \%$ and $20 \%$ & Level 1: Precursor \\
\hline Between $21 \%$ and $40 \%$ & Level 2: Structured continuous improvement \\
\hline Between $41 \%$ and $60 \%$ & Level 3: Strategic continuous improvement \\
\hline Between $61 \%$ and $80 \%$ & Level 4: Proactive continuous improvement \\
\hline Between $81 \%$ and $100 \%$ & Level 5: Full capacity for continuous improvement \\
\hline
\end{tabular}

Table 2. Improvement maturity levels of the Bessant et al. (2001) model

\section{Methodology}

This research adopted multiple-case study methodology (Onwuegbuzie \& Leech, 2010; Yin, 2009), which is considered adequate to obtain information about social processes and to describe phenomena (Eisenhardt \& Graebner, 2007; Yin, 2009). Therefore, the authors contacted several large well-established and successful companies located in the Bogotá city in Colombia to verify their level of CIP application.

The authors chose four companies for the multi-case analysis based on the following selection criteria. The companies possess "ISO 9001:2015 Quality Management System" certification in the application of CI systems during the last two years. Their activity sector recognizes them by corporate image and reputation for their participation in the market with at least 30 years in operation. At last, they provided researchers access to their information and permitted interviews with their staff. Table 3 shows the main socio-demographic characteristics of the selected companies, where the company names have been changed to $\mathrm{C} 1, \mathrm{C} 2, \mathrm{C} 3$ and $\mathrm{C} 4$.

\begin{tabular}{|c|c|c|c|c|c|}
\hline Company & $\begin{array}{c}\text { Industrial } \\
\text { Sector }\end{array}$ & Age & Type & $\begin{array}{c}\text { Number of } \\
\text { employees (2018) }\end{array}$ & $\begin{array}{c}\text { Duration of continuous } \\
\text { improvement programmes }\end{array}$ \\
\hline $\mathrm{C} 1$ & $\begin{array}{c}\text { Consumer } \\
\text { goods }\end{array}$ & $>30$ years & $\begin{array}{c}\text { Colombian } \\
\text { Multinational }\end{array}$ & 4,047 & $>10$ years \\
\hline $\mathrm{C} 2$ & Food & $>50$ years & $\begin{array}{c}\text { Colombian } \\
\text { Multinational }\end{array}$ & 1,028 & $>2$ years \\
\hline $\mathrm{C} 3$ & $\begin{array}{c}\text { Consumer } \\
\text { goods }\end{array}$ & $>100$ years & $\begin{array}{c}\text { Colombian } \\
\text { Multinational }\end{array}$ & 2,044 & $>12$ years \\
\hline
\end{tabular}

Table 3. Characteristics of the companies participating in the study

C1 is a Colombian multinational consumer goods company dedicated to the production and commercialization of more than 30 successful brands of products in the categories of food, personal care, home care, snacks and beverages. It is one of the five largest manufacturers of consumer goods in Colombia and operates in the main cities of the country. Since its foundation, its fundamental principles have been management, the comprehensive personal and professional development of work team members. Currently, it has 4047 employees in Colombia.

C2 is a Colombian multinational company dedicated to the production of snacks, with more than 50 years in operation. Due to its sales and market share, it is one of the three most recognized companies in the Ready-To-Eat food and snack sector. Currently, the company has presence in England, the United States, Panama and Spain; it has 1028 Colombian employees. Since its inception, the company has searched for new technologies to mitigate the impact of its production processes on the environment. In recent years, it has decreased its electricity consumption by $5 \%$ and reduced its annual carbon footprint by approximately $20 \%$. 
C3 is a Colombian multinational company dedicated to the production, marketing and distribution of consumer goods, with more than 110 years in the market. It has three factories, two for food manufacturing and one for cleaning, personal care and domestic cleaning products. Currently, its products sell in more than 40 countries. In 2017, it is one of the 150 largest companies in the country. The company has 2044 employees.

C4 is a multinational company dedicated to the production and distribution of energy distribution systems for the automotive industry. The factory in Colombia has 969 employees, and since its inception, CI has been an integral part of the company's principles.

The data collection process considers different sources. These sources include the documents provided by the companies, information on the companies' websites, interviews and surveys with the leaders and operation managers, and observations during repeated visits to their facilities in a limited period between February and April of 2018. The content analysis of the companies' documents and websites identifies information about the industrial sector, quantity of years participating in the market, amount of employees, financial profile, recognition criteria, and the reasons behind the adoption of CI policies. Consequently, two experts validated the interview questions, and the authors applied it to the Chief Executive Officer (CEO) or the production manager of each company for approximately 60-90 minutes. The interview topics are CI related, particularly the key success factors and barriers presented in Appendix A.

In addition, the same high-level managers responded to the survey to measure the CI program maturity level by applying the Bessant et al. (2001) model and to evaluate the barriers of CIS success utilizing Likert-type items.

The authors made visits to each factory various times and each visit lasted for approximately between 90 and 120 minutes to observe and validate the information in relation to CI success factors and barriers. The intermediate managers or the production manager directed the visits. They presented and explained how they perform their tasks, productive activities and improvements. In all cases, the visit completed by a discussion with the managers to clarify the principles behind the behaviours and tasks observed.

Finally, the collected data from the survey of the higher management was analysed applying descriptive statistical analysis aligned with the Bessant et al. (2001) model. The authors conducted a comparative analysis of the CI maturity level measurment and barriers of sustainability in the companies.

\section{Results and Discussion}

The CEOs that participated in the study mentioned that the implemented policy of quality and CI are to achieve the goals of sustainable development, profitable growth, satisfaction of customer needs, and well-being of all people working in the company and mitigating the impacts that their production processes and their products may have on the environment. The companies apply this policy to add value in manufacturing processes permanently.

\subsection{Analysis of CIS Key Success Factors and Barriers}

Figure 1 indicates that only companies C2 and C4 registered high scores in more than $70 \%$ of the key success factor descriptors identified in the literature. Overall, all four companies perform systematic activities applying CIP under specific programs and with dedicated teams that comply with policies clearly defined by the management.

There is abundant research about significant factors that guaranty the CI programs' success. However, the significant factors identified in the prior research are not conclusive (Sánchez-Ruiz et al., 2018). This is much more evident, in the case of companies in the emerging economies, where research on the subject is very scarce (González-Aleu \& Van Aken, 2016). In this sense, the results of this study contribute to the understanding of the subject by providing empirical evidence. The results indicate that success of this improvement is due to few factors such as availability of resources; management commitment and support; employee participation in the identification of improvement tasks; clear and realistic continuous improvement objectives; and, existence of a leader or responsible person for continuous improvement actions. 


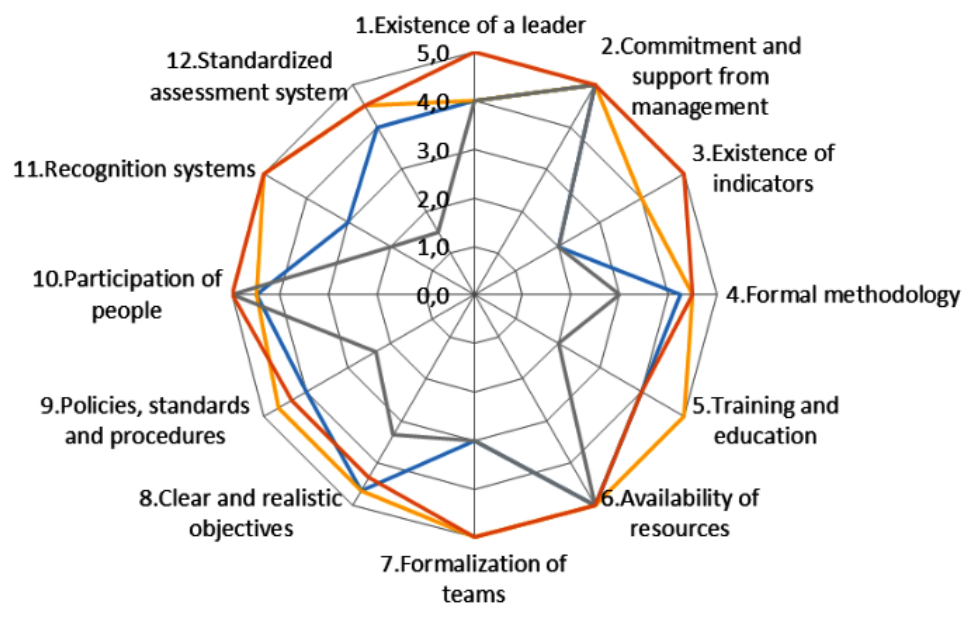

Figure 1. Results of the assessment of the key success factors for companies C1, C2, C3 and C4

Likewise, the results validate the importance of the key success factors mentioned by García-Sabater and Marín-García, (2009), Jaca et al. (2012), Bateman and Rich, (2003), Prajogo and Sohal, (2004) Sánchez-Ruiz et al. (2019), McLean and Antony (2014). These factors are the commitment of the managers; the availability of resources (money, time, technologies, etc.); participation of employees in the identification, definition, and finding the means for improvement activities; the clarity of the objectives; the scope of improvements; and, finally, the presence of responsible leader. In addition, training scored low among other parameters in the studied companies and contrasts with the conclusions by McLean and Antony (2014), Jaca et al. (2011), Sánchez-Ruiz et al. (2019), Bessant and Francis (1999) Jørgensen et al. (2006); and López et al. (2009). In the developed economies, training is a key factor in all business activities, and it is the companies' commitment to their employees, while in countries of emerging economies such as Colombia, training is initially the employee's resposibility.

In contrast, in Figure 2 the results of the three companies score high in the following barriers: lack of alignment between organization's strategic objectives and continuous improvement objectives; lack of motivation in the team; and, resistance to change. The managers indicated that employees do not see an alignment between CIP goals and organizational objectives, and as a result, they do not feel motivated. The main issue is not the lack of communication or CI tools as affirmed by Bateman and Rich (2003), but incoherence of the communicated information with the reality of the objective and their implementation in the company. As a result, they resist to all CI related changes that in their perception conflict with the organizations objectives.

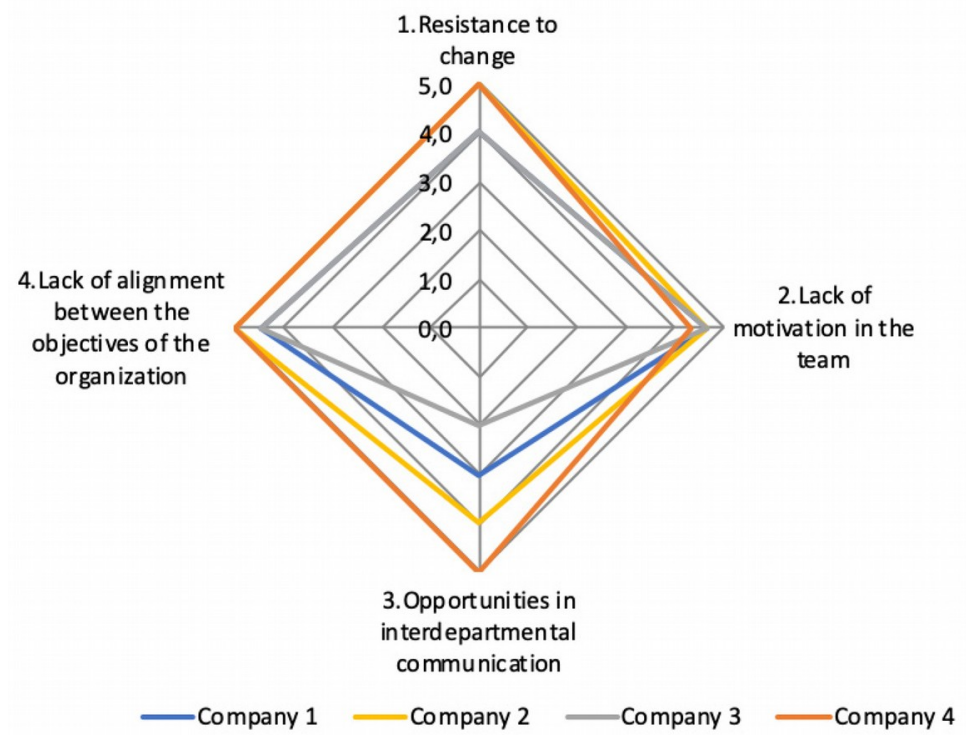

Figure 2. Results of the assessment of the major barriers for companies C1, C2, C3 and C4 
The results narrow the diverse amount of success factors mentioned by González-Aleu and Van Aken (2016) and the barriers identified by Sánchez-Ruiz et al. (2018), Jaca et al. (2011), Jayaraman et al. (2012), Michcol et al. (2012) for companies in emerging economies.

As a synthesis of the evidence in the four companies studied, Table 4 presents the key lessons learned based on the survey results in order of importance, specifically the main factors (success and barriers), and the corresponding behaviours, that were considered fundamental to the sustainability achievement of their CI systems

\begin{tabular}{|c|c|c|c|}
\hline Key success factor & Behaviours & Major barriers & Behaviours \\
\hline $\begin{array}{l}\text { Availability of } \\
\text { resources }\end{array}$ & $\begin{array}{l}\text { The management must ensure } \\
\text { the availability of the necessary } \\
\text { resources for the } \\
\text { implementation (personnel, } \\
\text { economic, time, etc.). }\end{array}$ & $\begin{array}{l}\text { Lack of alignment } \\
\text { between the } \\
\text { organization's } \\
\text { objectives }\end{array}$ & $\begin{array}{l}\text {-Management should identify and } \\
\text { clarify the objectives and priorities } \\
\text { of the organization to select the } \\
\text { best improvement methodology. }\end{array}$ \\
\hline $\begin{array}{l}\text { Commitment and } \\
\text { support from } \\
\text { management }\end{array}$ & $\begin{array}{l}\text { - Management should support the } \\
\text { implementation of the defined } \\
\text { methodology. } \\
\text { - Management must be involved } \\
\text { and be an integral part of the } \\
\text { improvement projects. } \\
\text { - Management must foster the } \\
\text { culture of continuous } \\
\text { improvement. }\end{array}$ & $\begin{array}{l}\text { Lack of motivation in } \\
\text { the team }\end{array}$ & $\begin{array}{l}\text { - Management should facilitate the } \\
\text { generation of expectations } \\
\text { campaigns. } \\
\text {-Management should raise awareness } \\
\text { about staff improvement. } \\
\text {-Management should allow staff to } \\
\text { make improvement proposals. }\end{array}$ \\
\hline $\begin{array}{l}\text { Participation of the } \\
\text { employees }\end{array}$ & $\begin{array}{l}\text { - The person proposing the } \\
\text { improvement must participate in } \\
\text { the implementation, which } \\
\text { reinforces the empowerment of } \\
\text { the individual and the team. }\end{array}$ & \multirow{3}{*}{ Resistance to change } & \multirow{3}{*}{$\begin{array}{l}\text {-Management should design } \\
\text { awareness programs regarding the } \\
\text { CI methodology and the benefits } \\
\text { associated with the continuous } \\
\text { improvement programs. } \\
\text { - Management should generate a } \\
\text { culture that understands } \\
\text { improvements are not additional } \\
\text { tasks. It is an organizational } \\
\text { integrated process to achieve } \\
\text { better results. }\end{array}$} \\
\hline $\begin{array}{l}\text { Clear and realistic } \\
\text { objectives }\end{array}$ & $\begin{array}{l}\text { - Define long, medium and short- } \\
\text { term objectives for the } \\
\text { implementation of the defined } \\
\text { methodology. } \\
\text { - Delimit the scope of } \\
\text { implementation very well. } \\
\text { - Define control mechanisms that } \\
\text { allow the demonstration of } \\
\text { compliance with each objective. } \\
\text { - Define control points that allow } \\
\text { the demonstration of stability in } \\
\text { the implementation of } \\
\text { improvement. }\end{array}$ & & \\
\hline Existence of a leader & $\begin{array}{l}\text { - There must be a leader in the } \\
\text { implementation of continuous } \\
\text { improvement who is responsible } \\
\text { for the control and monitoring } \\
\text { of the improvement plans. } \\
\text { - This person should be dedicated } \\
\text { only to the implementation, not } \\
\text { as an additional task to the } \\
\text { operations of another position. }\end{array}$ & & \\
\hline
\end{tabular}

Table 4. Main behaviours applied by the organizations for the sustainability of continuous improvement 


\subsection{Maturity Analysis of Continuous Improvement Programs}

Regarding the maturity status of the CI programs, Figures 1, 2, 3, and 4 show the main outcomes of Bessant et al. (2001) model for each company.

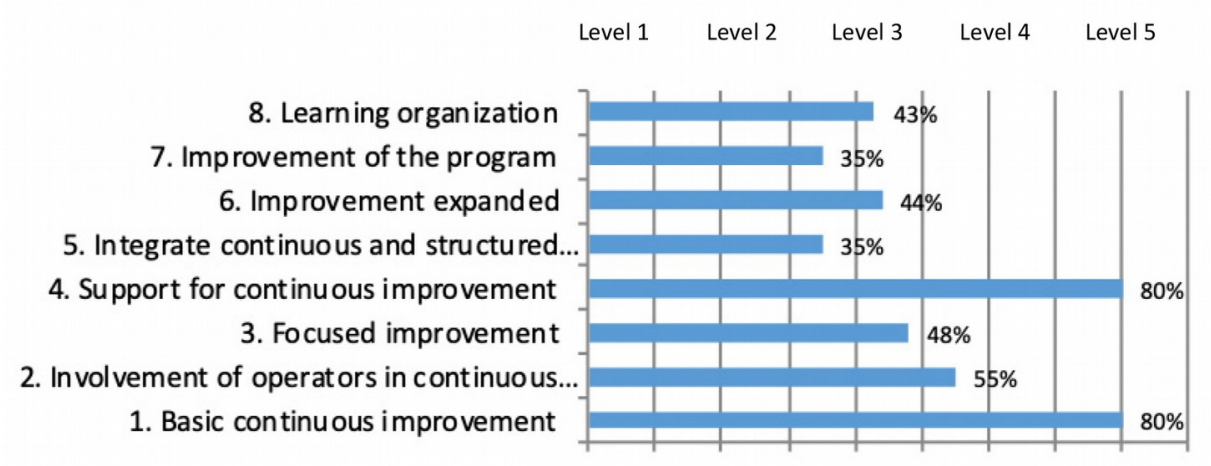

$0 \% \quad 10 \% \quad 20 \%$ 30\% $40 \%$ 50\% $60 \%$ 70\% $80 \%$ 90\%

52\% - Level 3: Strategic continuous improvement

The evidence of staff participation at all levels in the identification and deployment of CI plans is clear. The observation is that for each problem, the company carries out a root cause analysis through a formal and standardized methodology. Management is fully empowered in the selection, assessment and deployment of CI plans, assigning all the necessary resources. The company approves ach plan if it contributes to the improvement of the outcomes of the organization's objectives.

Figure 3. Maturity level in C1

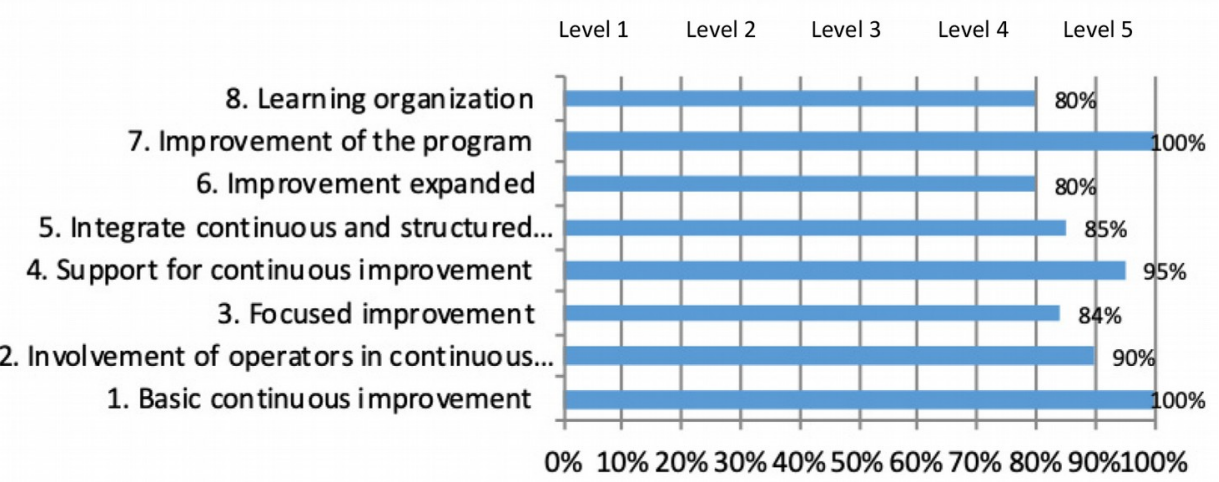

89\% Level 5: Full capacity for continuous improvement

Clear progress in all behaviours is evident. The CI system implemented empowers all personnel throughout the organization. Management is fully empowered in the selection, assessment and deployment of CI plans, assigning all the necessary resources. There are personnel for CI dedicated to measuring and ensuring the implementation of the plans in a standardized manner.

Figure 4. Maturity level in C2

The maturity outcomes suggest that companies C2 and C4 are the most advanced in the implementation of CI according to the model of Bessant et al. (2001). In these two companies, there is a complete compliance in the behaviour of basic CI and program improvement. The data from these two companies (C2 and C4) indicate that there are important practices associated with each behaviour, and there is evidence of a genuine empowerment by the management of each company and the personnel in general. Accordingly, CI is present as an integral part of the companies' operations, and as a result, the strategies defined for CI flow naturally as part of day-to-day tasks. 
Additionally, in companies C1 and C3, although CI consolidation is not according to the model of Bessant et al. (2001), there is a high commitment to CI behaviour towards building a sustaining culture. Therefore, according to the cited model, these companies need to continue formalizing an improvement program aligned with the organizational objectives.

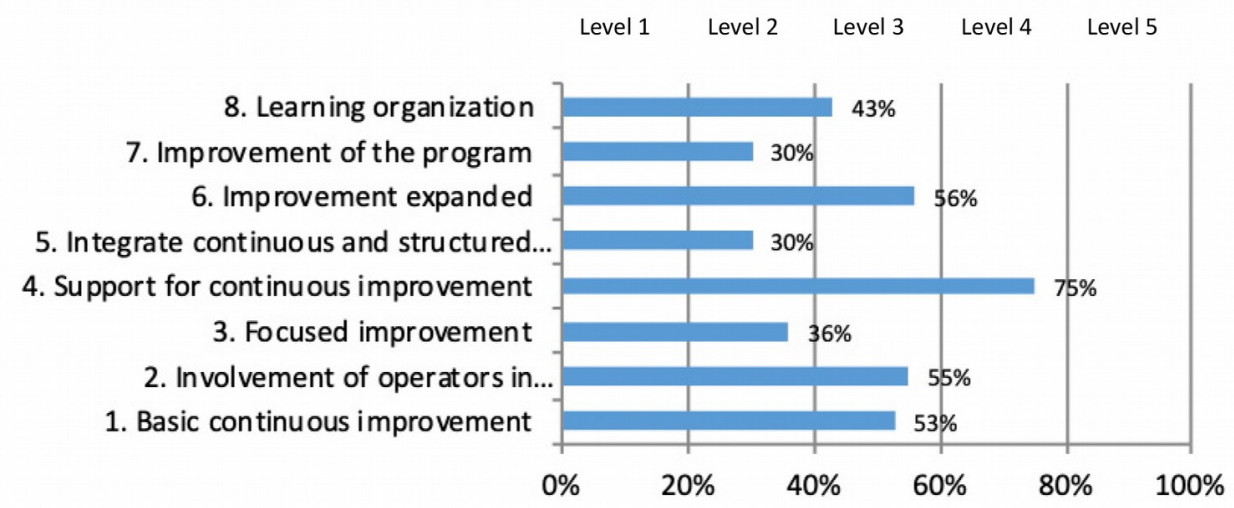

47\% - Level 3: Strategic continuous improvement

The evidence of staff participation at all levels in the identification and deployment of CI plans is clear. The observation is that for each problem, the company carries out a root cause analysis through a formal and standardized methodology. Management is fully empowered to perform the selection, assessment and deployment of CI plans, assigning all the necessary resources. A consulting company provides assistance.

Figure 5. Maturity level in C3

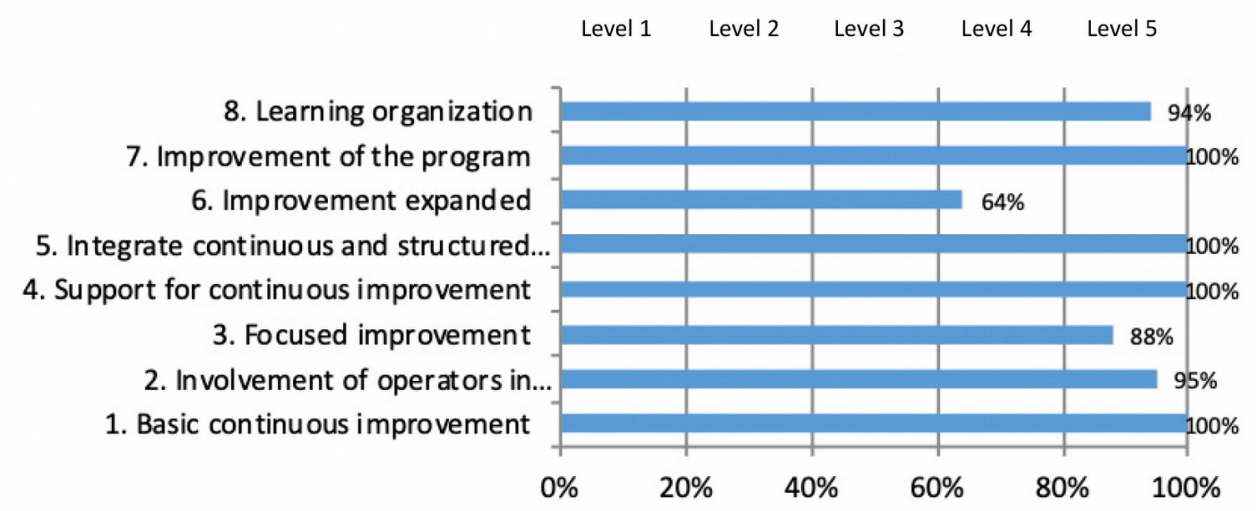

93\% - Level 5: Full capacity for continuous improvement

The corporate policy defined by headquarters ensures the empowerment of all personnel in the CI system implemented throughout the organization. They have their own continuous improvement system, with standardized tools to conduct the selection, assessment and deployment of each CI plan, which the management approves that ensures the availability of all resources. There is a CI department dedicated to measuring and ensuring the implementation of the plans in a standardized manner in all subsidiaries.

Figure 6. Maturity level in C4

An empirical evidence provided by the four companies in emerging economies provide guidelines that ensure the CIS. The identified key behaviours ensure that their improvement system achieves a high maturity level (Table 5). The relation between the behaviours and the routines is possible by applying the parameters from Table 1 with the highest scores achieved from the four companies studied. For example, the managers stated that, in order to achieve a basic CI (routine 1), companies need to carry out the following behaviours: guarantying the training of new personnel in the areas of standardized methodology and tools for problem-solving and have a policy regarding 
the analysis of root causes of the activities that need improvement. In order to involve employees in CI (routine 2), the following behaviours are necessary: possessing standard tools for the analysis; deployment and evaluation of CI; definition of a plan to receive and prioritize proposals for CI with timely communication to employees; and, definition of an agreement with the employee's indicators associated with continuous improvement. Employee participation in the definition of CI indicators is very important because this gives clarity to what needs to be improved and when to achieve it.

\begin{tabular}{|c|c|}
\hline Routine & Behaviours \\
\hline $\begin{array}{l}\text { 1. Basic } \\
\text { continuous } \\
\text { improvement }\end{array}$ & $\begin{array}{l}\text { - Ensure the training of new personnel in the methodology topics and standardized tools for } \\
\text { problem solving. } \\
\text {-Define a policy that legislates when to conduct a root cause analysis. }\end{array}$ \\
\hline $\begin{array}{l}\text { 2. Involvement } \\
\text { and participation }\end{array}$ & $\begin{array}{l}\text {-Define standard tools for the analysis, deployment and assessment of continuous improvement. } \\
\text {-Define a plan for receiving and prioritizing proposals for continuous improvement with timely } \\
\text { communication to the operators. } \\
\text {-Define indicators associated with continuous improvement. }\end{array}$ \\
\hline $\begin{array}{l}\text { 3. Focused } \\
\text { improvement }\end{array}$ & $\begin{array}{l}\text {-Disclose the strategic objectives of the organization at all levels. } \\
\text { - Ensure that the entire team understands the effect of the proposal, planning and deployment of } \\
\text { the continuous improvement plans on strategic objectives of the organization. } \\
\text {-Design a measurement system that allows the visualization of the progress and/or fulfilment of } \\
\text { the improvement plans and the analysis of the impact of these on the strategic objectives of } \\
\text { the organization. } \\
\text {-Ensure the alignment of any improvement plan with the strategic objectives of the organization. }\end{array}$ \\
\hline $\begin{array}{l}\text { 4. Support for } \\
\text { improvement }\end{array}$ & $\begin{array}{l}\text { - Ensure the availability of all the necessary resources for the implementation of improvement } \\
\text { plans. } \\
\text { - Management must be an active part in the implementation in order to generate ownership and } \\
\text { empowerment in the team. } \\
\text { - Conduct pilot tests. }\end{array}$ \\
\hline $\begin{array}{l}\text { 5. Integrate } \\
\text { continuous and } \\
\text { structured } \\
\text { improvement }\end{array}$ & $\begin{array}{l}\text {-Design an assessment process for the implementation of continuous improvement, oriented to } \\
\text { validate whether the defined structure is adequate to ensure the implementation and } \\
\text { sustainability of the improvement plans. } \\
\text {-Define the scope, stages and procedure of the improvement plan. } \\
\text { - Periodically monitor the deployment of the improvement plans and validate if the structure is } \\
\text { adequate to ensure compliance with the defined objectives. }\end{array}$ \\
\hline $\begin{array}{l}\text { 6. Improvement } \\
\text { expanded }\end{array}$ & $\begin{array}{l}\text { - Conduct awareness campaigns for the collaborators to generate an understanding of the impact } \\
\text { that their work generates on the company's general outcomes and how they affect the other } \\
\text { areas positively or negatively. } \\
\text { - Generate improvement plans that involve suppliers and customers. }\end{array}$ \\
\hline $\begin{array}{l}\text { 7. Improvement } \\
\text { of the program }\end{array}$ & $\begin{array}{l}\text {-Define a long-term programme for the continuous improvement of an area, with clear and } \\
\text { measurable objectives, that allows visualizing the level of progress and compliance with this. } \\
\text {-Ensure that there is a feedback process in the improvement plan that allows its constant } \\
\text { assessment and restructuring. }\end{array}$ \\
\hline $\begin{array}{l}\text { 8. Learning } \\
\text { organization }\end{array}$ & $\begin{array}{l}\text {-Define the procedure and tools necessary to consolidate and disseminate the generated learning } \\
\text { when applying improvement plans. } \\
\text { - Generate repeatable policies of good practices. } \\
\text {-Design tools that develop self-learning in workers. }\end{array}$ \\
\hline
\end{tabular}

Table 5. Key lessons learned and behaviours to promote the maturity of continuous improvement 


\section{Conclusions}

The absence of a single or a group of dominant publications outlets is evidence of lack of maturity in CIS. The literature review indicates that there is a great deal of research about CIS in the countries of developed economies; however, their results are controversial, which evidences the need for new studies on the subject.

The empirical study results indicate five success factors and three barriers that companies should consider while implementing sustainable continuous improvement programs. The key success factors listed are in order of most important: availability of resources; commitment and support from management; the participation of employees in the identification of tasks to improve; clear and realistic objectives to CI; and, finally, existence of a leader or responsible for CI. The major barriers of CIS success are lack of alignment between organization's strategic objectives and CI objectives; lack of motivation in the team; and, resistance to change. The results confirm that, in spite the high level of maturity in the companies, in order to motivate employees for their participation in improvement processes and generate improvement plans that involve suppliers and customers it is necessary to align the organization's strategic objectives with continuous improvement objectives.

The presented research is limited to: first, multi-case study applying qualitative approach in terms of reliability, validity, and generalizability of the results; secondly, CI is used in a broad sense without analysing each tool, methodology (e.g. Six Sigma, Lean, Kaizen, etc.), or context (cultural, societal and economic) in detail. However, it has applicability and validity for companies of the similar size, sectors and contexts as the studied companies. Additionally, the study offers interesting insights on the empirical evidence on the lessons learned from $\mathrm{CI}$ practices in order to support managers on better decision making and understanding of CI for research.

Consequently, future research can contribute by focusing on new multi-case studies, mixed focus studies with the inclusion of large number of companies to evaluate and validate our results in relation to organization's CI processes and performance. The research is necessary to validate the generality of the results in the companies that apply different techniques of CI (e.g. Six Sigma, Lean, Kaizen, etc.). Future research is able to contribute to our understanding of CIS by the inclusion of other additional factors that can affect the results such as company size, industrial sector, public vs. private, countries or geographical regions (considering cultural, societal and economic context), longitudinal and cross-sectional studies with representative statistical samples of the companies. It is necessary to conduct research that facilitates manager and employee training that enables them to design, implement and measure the CIS programs. Finally, in order to integrate the research in this subject area it is necessary to conduct systematic literature reviews applying text mining and natural language processing techniques to screen large quantity of documents that permits the development of a comprehensive framework with more dimensions and criteria.

\subsection{Theoretical and managerial implications}

The significance of the present research is that it provides a conceptual framework of factors and barriers that affect CIS and analyses them with the empirical evidence from four large recognized companies in an emerging economy. As a result, the study establishes five key success factors and three major barriers to sustain CI in the companies studied (Figure 7).

The results of the research presented here are important for a better understanding of success and failure factors of $\mathrm{CI}$ in companies and are beneficiary for decision-making by entrepreneurs and CIP managers. The reason is that $\mathrm{CI}$ is currently an important strategy for the company's competitiveness in the contexts of emerging economies as it is a way to carry out processes of change or improvement in products, production processes, and related activities such as marketing and business administration. The work in the companies of emerging economies tend to be labour intensive rather than automated, but similar to the companies in the developed countries, they need to respond effectively to the constant and rapid changes of the environment, global competition and market uncertainty. 


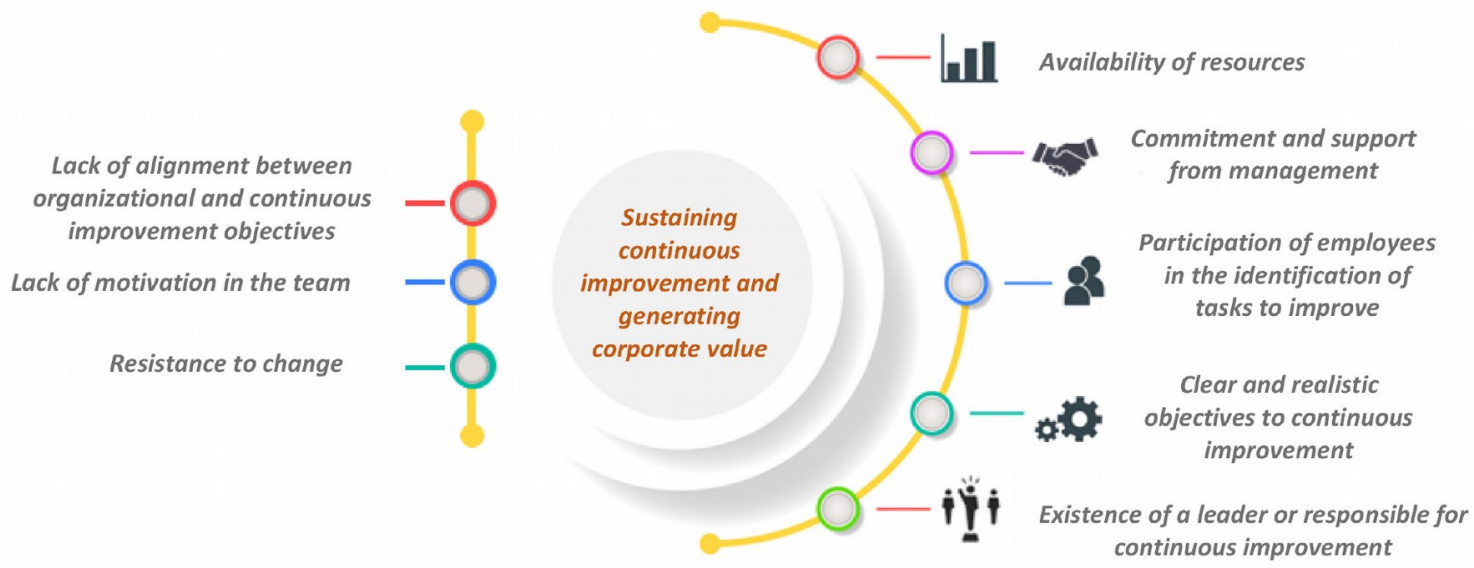

Figure 7. Key success factors and barriers for the CIS of companies of emerging economies

\section{Declaration of Conflicting Interests}

The authors declared no potential conflicts of interest with respect to the research, authorship, and/or publication of this article.

\section{Funding}

The authors received no financial support for the research, authorship, and/or publication of this article.

\section{References}

Albors, J., Hervás-Oliver, J.L., \& Segarra-Oña, M. del V. (2009), Análisis de las prácticas de mejora continua en España: barreras y facilitadores. Economía Industrial, 373, 185-195.

Anand, G., Ward, P.T., Tatikonda, M.V., \& Schilling, D.A. (2009). Dynamic capabilities through continuous improvement infrastructure. Journal of Operations Management, 27(6), 444-

461.https://doi.org/10.1016/j.jom.2009.02.002

Anthony, J., \& Banuelas, R. (2002). Critial success factor for the successful implementing of Six Sigma projects. The TQM Magazines, 41(2), 92-99. https:// doi.org/10.1108/09544780210416702

Barraza, M.F.S., \& Dávila, J.Á.M. (2009). Encontrando al kaizen: un análisis teórico de la mejora continua. Pecunia, 7 , 285-311. https://doi.org/10.18002/pec.v0i7.696

Bateman, N. (2005). Sustainability: the elusive element of process improvement. International Journal of Operations \& Production Management, 25(3), 261-276. https://doi.org/10.1108/01443570510581862

Bateman, N., \& David, A. (2002). Process improvement programmes: a model for assessing sustainability. International Journal of Operations \& Production Management, 22(5), 515-526.

https://doi.org/10.1108/01443570210425156

Bateman, N., \& Rich, N. (2003). Companies' perceptions of inhibitors and enablers for process improvement activities. International Journal of Operations \& Production Management, 23(2), 185-199. https://doi.org/10.1108/01443570310458447

Berger, A. (1997). Continuous improvement and kaizen: standardization and organizational designs. Integrated Manufacturing Systems, 8(2), 110-117. https://doi.org/10.1108/09576069710165792

Bessant, J., Caffyn, S., \& Gallagher, M. (2001). An evolutionary model of continuous improvement behavior. Technovation, 21(2), 67-77. https://doi.org/10.1016/S0166-4972(00)00023-7

Bessant, J., \& Francis, D. (1999). Developing strategic continuous improvement capability. International Journal of Operations \& Production Management, 19(11), 1106-1119. https://doi.org/10.1108/01443579910291032

Bessant, J., \& Caffyn, S. (1997). High-involvement innovation through continuous improvement. International Journal of Technology Management, 14(1), 7-28. https://doi.org/10.1504/IJTM.1997.001705 
Bhuiyan, N., Baghel, A., \& Wilson, J. (2006). A sustainable continuous improvement methodology at an aerospace company. International Journal of Productivity and Performance Management, 55(8), 671-687.

https://doi.org/10.1108/17410400610710206

Borgianni, Y., Cascini, G., \& Rotini, F. (2015). Business process reengineering driven by customer value: a support for undertaking decisions under uncertainty conditions. Computers in Industry, 68, 132-147.

https://doi.org/10.1016/j.compind.2015.01.001

Caffyn, S. (1999). Development of a continuous improvement self-assessment tool. International Journal of Operations \& Production Management, 19(11), 1138-1153. https://doi.org/10.1108/01443579910291050

Cooney, R., \& Sohal, A. (2004). Teamwork and total quality management: a durable partnership. Total Quality Management \& Business Excellence, 15(8), 1131-1142. https:/ / doi.org/10.1080/1478336042000255442

Dale, B.G., Boaden, R.J., Wilcox, M., \& McQuater, R.E. (1997). Sustaining total quality management: what are the key issues? The TQM Magazine, 9(5), 372-380. https://doi.org/10.1108/09544789710178668

Eisenhardt, K.M., \& Graebner, M.E. (2007). Theory building from cases: opportunities and challenges. Academy of Management Journal, 50(1), 25-32. https://doi.org/10.5465/amj.2007.24160888

Formento, H., Chiodi, F., Cusolito, F., Altube, L., \& Gatti, S.P. (2013). Key factors for a continuous improvement process. Independent Journal of Management \& Production, 4(2), 391-415. https://doi.org/10.14807/ijmp.v4i2.76

García-Sabater, J.J., \& Marín-García, J.A. (2011). Can we still talk about continuous improvement? Rethinking enablers and inhibitors for successful implementation. International Journal of Technology Management, 55(1), 28-42. https://doi.org/10.1504/IJTM.2011.041678

García-Sabater, J.J., \& Marín-García, J.A. (2009). Facilitadores y barreras para la sostenibilidad de la mejora continua: un estudio en proveedores del automóvil de la comunidad valenciana. Intangible Capital, 5(2), 1697-9818.

González-Aleu, F., \& Van Aken, E.M. (2016). Systematic literature review of critical success factors for continuous improvement projects. International Journal of Lean Six Sigma, 7(3), 214-232. https://doi.org/10.1108/IJLSS-06-20150025

Garrigós, J.A., Oliver, J.L.H., \& Oña, M.D.V.S. (2009). Análisis de las prácticas de mejora continua en España: barreras y facilitadores. Economía industrial, 373, 185-195.

Hammer, M., \& Champy, J. (1994). Reingeniería de la Empresa: Olvide lo Que Usted Sabe Sobre Cómo Debe Funcionar Una Empresa, ¡Casi Todo Está Equivocado! Bogotá: Grupo Editorial Norma.

He, Z. (2009). Progress report: learn something about your six-sigma program's maturity. Quality Progress, 24(4), 22-28.

Imai, M. (2012). La Clave de la Ventaja Competitiva Japonesa. México: Cecsa.

Jaca, C., Suárez-Barraza, M., Viles, E., Mateo, R., \& Santos, J. (2011). Encuesta de sostenibilidad de sistemas de mejora continua: comparativa de dos comunidades industriales de España y México. Intangible Capital, 7(1), 1697-9818. https://doi.org/10.3926/ic.2011.v7n1.p143-169

Jaca, C., Viles, E., Mateo, R., \& Santos, J. (2012). Components of sustainable improvement systems: theory and practice. The TQM Journal, 24(2), 142-154. https://doi.org/10.1108/17542731211215080

Jayaraman, K., Kee, T.L., \& Soh, K.L. (2012). The perceptions and perspectives of lean six sigma (LSS) practitioners: An empirical study in Malaysia. The TQM Journal, 24(5), 433-446.

https://doi.org/10.1108/17542731211261584

Jørgensen, F., Boer, H., \& Laugen, B.T. (2006). CI implementation: an empirical test of the CI maturity model. Creativity and Innovation Management, 15(4), 328-337. https://doi.org/10.1111/j.1467-8691.2006.00404.x

Juran, J.M., Ballester, M.G., \& Medina, J.N. (1990). Juran y la Planificación Para la Calidad. España: Díaz de Santos.

López, R.R., Morales, S.A.N., Toledo, C.E.E., \& Delgado, V.I.A. (2009). Factores críticos de éxito una estrategia de competitividad. Cultura Cientifica y Tecnológica, 6(31), 5-14.

Marín-García, J.A., \& García-Sabater, J.J. (2010). Traducción al castellano de un cuestionario para identificar conductas de la mejora continua y etapas en el modelo de evolución. WPOM-Working Papers on Operations Management, 1(1), 18-26. https://doi.org/10.4995/wpom.v1i1.793 
McLean, R.S., Antony, J., \& Dahlgaard, J.J. (2017). Failure of continuous improvement initiatives in manufacturing environments: a systematic review of the evidence. Total Quality Management \& Business Excellence, 28(3-4), 219-237. https://doi.org/10.1080/14783363.2015.1063414

McLean, R., \& Antony, J. (2014). Why continuous improvement initiatives fail in manufacturing environments? A systematic review of the evidence. International Journal of Productivity and Performance Management, 63(3), 370-376. https://doi.org/10.1108/IJPPM-07-2013-0124

Michcol, J.T., Cano, P., Farías, S.F., \& Morales, J.J.N. (2012). Análisis de facilitadores para sostener la mejora continua en una empresa de autopartes. Conciencia Tecnológica. Departamento de Desarrollo Académico, 1(44), 41-50.

Onwuegbuzie, A.J., \& Leech, N.L. (2010). Generalization practices in qualitative research: a mixed methods case study. Quality \& Quantity, 44(5), 881-892. https:/ / doi.org/10.1007/s11135-009-9241-z

Porter, M.E. (1985). The Competitive Advantage: Creating and Sustaining Superior Performance. New York, NY: Free Press.

Prado, J.C.P., Fernández-González, A.J., \& García-Lorenzo, A. (2004). Quality management and personnel participation: improvement teams, a solution for ISO 9000 system maintenance problems in small to medium-sized enterprises. Human Factors and Ergonomics in Manufacturing \& Service Industries, 14(3), 221-237. https://doi.org/10.1002/hfm.10061

Prajogo, D., \& Sohal, A. (2004). The sustainability and evolution of quality improvement programmes - an Australian case study. Total Quality Management \& Business Excellence, 15(2), 205-220. https://doi.org/10.1080/1478336032000149036

Sánchez-Ruiz, L., Blanco, B., \& Gomez-Lopez, R. (2019). Continuous improvement enablers: Defining a new construct. Journal of Industrial Engineering and Management, 12(1), 51-69. https://doi.org/10.3926/jiem.2743

Sánchez-Ruiz, L., Blanco, B., \& Diaz, E. (2018). Difficulty in implementing continuous improvement-Rasch measurement analysis. Business Process Management Journal, 25(6), 1228-1250. https://doi.org/10.1108/BPMJ-05-20170125

Singh, J., \& Singh, H. (2015). Continuous improvement philosophy - literature review and directions. Benchmarking: An International Journal, 22(1), 75-119. https://doi.org/10.1108/BIJ-06-2012-0038

Upton, D.M. (1996). Mechanisms for building and sustaining operations improvement. Technology and Operations Management, 95(54), 1-28. https://doi.org/10.1016/0263-2373(96)00002-3

Yin, R. (2009). Case Study Research Design and Methods. India: Calif Sage Publication.

Zairi, M. (2005). TQM Sustainability: How to Maintain Its Gains through Transformational Change. Bradford: University of Bradford, School of Management.

Journal of Industrial Engineering and Management, 2020 (www.jiem.org)

\section{() (1) $\Theta$}

Article's contents are provided on an Attribution-Non Commercial 4.0 Creative commons International License. Readers are allowed to copy, distribute and communicate article's contents, provided the author's and Journal of Industrial Engineering and Management's names are included. It must not be used for commercial purposes. To see the complete license contents, please visit https://creativecommons.org/licenses/by-nc/4.0/. 